\title{
J
}

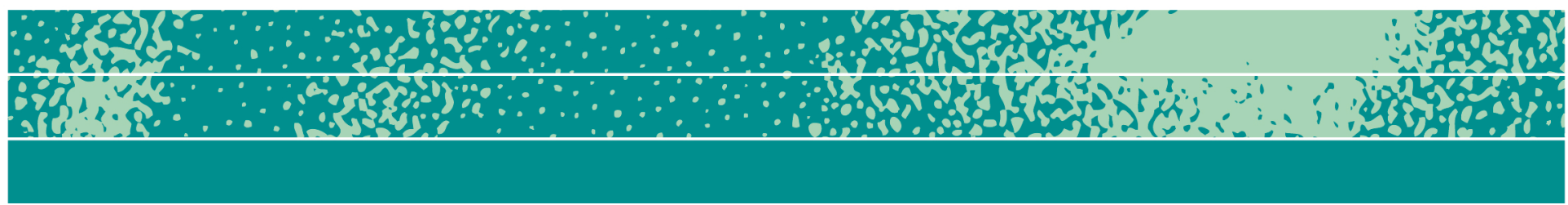

\section{From Brides to Business Owners: Microfinance and Women's Entrepreneurship}

Paromita Sanyal

\begin{abstract}
Women's entrepreneurship through microfinance programs has been celebrated as a model for reducing poverty and empowering women. Yet, evidence of the incidence of women's entrepreneurship has been disappointing, leading to much critique and controversy. This article presents case narratives of women enrolled in microfinance programs in rural India who took the leap onto entrepreneurship and used microcredit loans to expand or start their small-scale livelihoods enterprises. These narratives illustrate the particular economic and social conditions that are found in cases where women have transitioned from being dependent, gender-compliant housewives to sole-earners or main breadwinners. Marital failure, functional absence or retreat of husband, economic distress, living in a nuclear household, and absence of an adult son are consistently evident in all cases of women's entrepreneurship. This qualitative analysis helps us understand why women's entrepreneurship is not more widespread despite the availability of microcredit loans.
\end{abstract}

\section{Key words}

microfinance, microcredit, self-help groups, women's entrepreneurship,

\section{Page 1 of 23}

JBA 8(2): 250-272

Autumn 2019

(C) The Author(s) 2019

ISSN 2245-4217

www.cbs.dk/jba 
small-business, women's empowerment, agency, poverty reduction

With global proliferation, microfinance (alternatively termed microcredit) has become one of the most widespread contemporary development interventions. It is also one of the leading programs aimed at women who are economically vulnerable and socially disadvantaged in many societies around the world. Advocates of microcredit often rely rhetorically and ideologically on the supposed power of loans-to-women to transform them into "entrepreneurs." Such advocates hope that these loans will be a tool with which women can counteract the weight of normative restrictions and redress their economic dependency in their favor (Yunus 2007). Steeped in neoliberal ideologies, donor agencies and development organizations believe that microcredit will enable women to launch small businesses and become income earners, contributing financially to their households. With this change, it is expected that women's social status within their families will improve, their capabilities will be augmented, and the freedoms they enjoy will increase. Critics of neoliberal financialization, however, tend to be fiercely skeptical about the optimistic trope of "female entrepreneurship" in development discourses (Karim 2011; Kar 2018; Roy 2010). Even four decades after the emergence of microfinance, the propaganda and scholarship on it continue to be deeply divided.

This article focuses on women's entrepreneurship, stemming from using microcredit loans to expand or start small-scale livelihood businesses managed by women. The businesses span agriculture, animal husbandry, and other trades. They are characterized by women's selfemployment, with the occasional involvement of husbands and sons, usually in non-managerial roles. A case study approach is taken to analyze and feature narratives of entrepreneurship from women in different household settings: female-headed, egalitarian, and male-headed households. Drawing on these cases, the social and economic conditions under which women's entrepreneurship is realized are identified. It is important to identify these conditions since women's entrepreneurship is an exception to the prevailing practice of loan transfer from women to their husbands and grown sons. Therefore, knowing the conditions that can thrust women to this non-ordinary, even exceptional, outcome will advance our knowledge about entrepreneurship at the "bottom-of-thepyramid". This knowledge can help in formulating appropriate assistance aimed at supporting this unique group of entrepreneurs. It can also assist in formulating policies aimed at women's empowerment by untethering empowerment from the tenuous assumption that loans lead to entrepreneurship for all women.

The data informing this article are from a qualitative study of group-based microfinance and its effect on women's agency in rural India, 
for which 400 members were interviewed (Sanyal 2009, 2014, 2015; Davidson and Sanyal 2017). The findings on women's entrepreneurship were not promising, although for those women who had become entrepreneurs it was a very meaningful change. By analyzing the entrepreneurial cases in the larger data set, this article contributes to our understanding of the factors influencing who becomes a small-scale, selfemployed entrepreneur. It can also help address why access to credit is simply not enough to spark entrepreneurship among women in certain societal contexts.

\section{Microfinance and Entrepreneurship}

In the microfinance discourse, the term "entrepreneur" is used to refer to women who own and run economic enterprises or small businesses. In this popular usage, the term does not distinguish between a conventional or innovative business, business scale or profitability. This loose usage of entrepreneurship as a concept has emerged from organizational studies where it is used to reference anyone who starts an organization. The term has a much more specific meaning in the classical works of Schumpeter and others who use it to designate successful and profitable leadership of a capitalist firm (Becker, Knudsen, and Swedberg 2011; Swedberg 2000; Reuf 2010). Another use of the term has emerged recently in the figure of the "social entrepreneur;" the term is decoupled from the idea of founding an organization and still further removed from its original association of the leadership of a capitalist firm.

There is some dissension regarding the appropriateness of using "entrepreneurship" to refer to women's economic activities financed by microfinance loans. Some scholars argue that self-employment is more fitting because of the limited scope and size of the businesses, their uncertain profitability, and the absence of employment generation beyond the family. While recognizing the validity of this viewpoint, I have chosen to use "entrepreneurship" in keeping with the microfinance discourse and academic literature. There is also a substantive justification for retaining the term. Partially in keeping with its original meaning, using "entrepreneur" recognizes the initiative these women have taken, breaking from their conventional housewife and gender roles. It also acknowledges their acceptance and management of economic risks and business responsibilities in the face of hardships and hostile circumstances.

The relationship between microfinance and entrepreneurship has been investigated, and the results have been mixed. One set of studies, spanning many countries, found that access to microcredit increased business activity (Banerjee et al. 2015 a; Tarozzi et al 2015; Attanasio 2015; Crepon et al. 2015; Angelucci et al. 2015; Augsburg et al. 2015). The effects on business ownership, starts, and closures were modest, though 
not uniform across countries, and business size and profits were significantly improved (Banerjee et al. 2015 b). However, no distinction was made between family microentrepreneurial activity and womenowned and operated businesses. These findings have led scholars to conclude that, as long as interest rates are not exorbitant, microcredit leads to business creation and/or some expansion (Banerjee 2013). Ownership of consumer durables and business assets, especially livestock, increases. However, there is a concerning lack of evidence that links the growth of entrepreneurship to gains in household income, consumption, or improved health and education (Banerjee 2013). This gap is likely because the average business financed by microcredit is marginal and not very productive or profitable (Banerjee $2015 \mathrm{~b}$ ).

\section{Methodology}

The cases presented here draw on a qualitative database of 400 semistructured interviews conducted in 2004 for examining women's empowerment through microcredit. The goal of the research was to identify the mechanisms associated with improvements in women's agency. Was it the hyped financial mechanism of loans turning women into empowered entrepreneurs or the associational mechanism of group formation fostering social networks and leading to empowerment? Respondents were drawn from 59 self-help groups (SHGs) operating under two NGO-run microfinance programs (221 women from one and 179 from the other) in West Bengal, in the districts of North 24 Parganas and Nadia (See Figure 1). Thirty-four groups had all-Hindu members, 17 groups had all-Muslim members, and 8 had both Hindus and Muslims. 


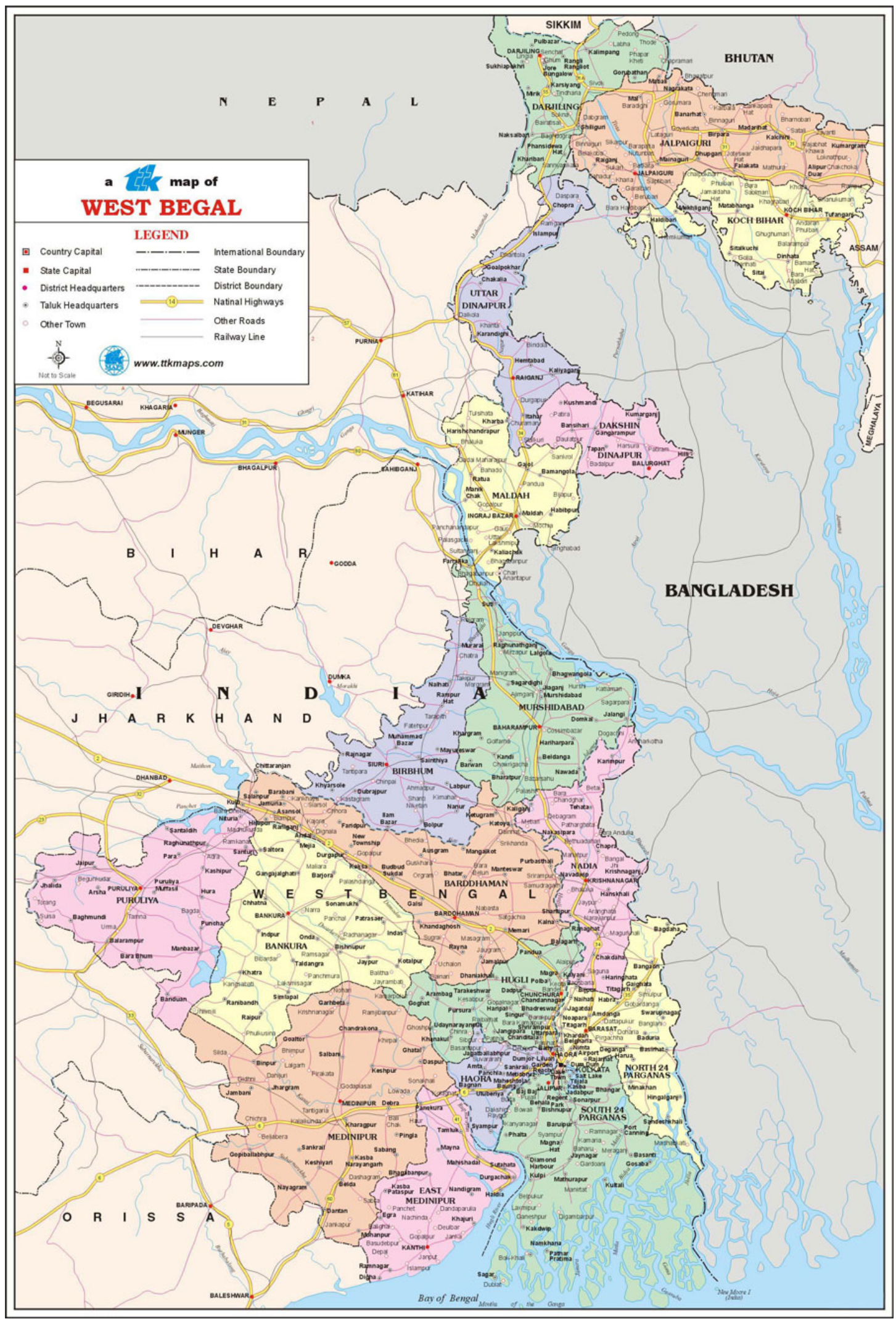

Figure 1. Map of West Bengal with Districts Marked*

*Fieldwork was done in North 24 Parganas and Nadia, districts on the bottom right-hand corner of the map. 
I interviewed the leaders and at least half of the members in each group and conducted the interviews in Bengali. The interviews were 40 minutes long on average. The homes of group leaders or members who did not have in-laws living with them were used as sites for interviewing. Women belonging to the same group and living in the same neighborhood came to the designated house to be interviewed. Interviews were conducted during the daytime when most of the husbands and neighborhood men were away at work, farming or plying their trades. The absence of men and senior household members from the interview sites facilitated fairly unrestricted communication. I tape-recorded, translated, and transcribed all the interviews into English.

The in-depth interviews focused on key themes related to women's agency, one of which was entrepreneurship. I asked women if they already operated a business or had started one after accessing the loans. I then learned about the household conditions, personal experiences, and spousal attitudes that had either facilitated this transition or had stood in the way. I then undertook qualitative causal analysis, formulating causal network diagrams for each case (Miles and Huberman 1994). The fundamental approach is to analyze personal accounts with the aim of identifying the outcome and the associated underlying variables and processes. For each case, I determined whether the respondent had improved agency, the process through which this change had come, and the mediating variables that exerted positive or negative influences. This inductive analysis led to identifying a range of "pathways to agency" (Sanyal 2014). From this original analysis, I have extracted the narratives of entrepreneurship for deeper analysis here.

Women who were entrepreneurs represented a variety of experiences and patterns that could be examined through the approach outlined above and that led to the identification of some key enabling circumstances. In the section below, I present case narratives that typify the profiles and patterns associated with women's entrepreneurship. The article's exclusive focus on women's entrepreneurship in connection with the accompanying conditions sets it apart from the rest of the scholarship which has neglected to analyze women's entrepreneurship because of its low incidence.

\section{Case Narratives}

Who are the entrepreneurial women that deviate from the general pattern of transferring loans to men or using the money to pay for household needs and emergencies? What are the factors that lead them to entrepreneurship? In the next few pages, 5 illustrative cases help answer these questions. 


\section{Entrepreneurship in Female-Headed Households}

Within the small number of women entrepreneurs, most belonged to female-headed households. This pattern is not unexpected since these women, particularly those without sons and those with young children, had no one else to rely on to provide for the family. These women had been either abandoned by their husbands, were estranged from them or widowed early. Most of them could not expect help from their in-laws after the loss or estrangement from their husbands. Returning to their natal families to live with their parents and brothers' families was not an option either due to hardships facing those families. Sometimes, the families were unwilling to take on the added burden. Therefore, in most of these cases, the women had to use their wits to find a way of fending for themselves and their children.

\section{Case 1}

Sophura Bibi belongs to a predominantly Muslim microcredit group that she helped form years ago with much struggle. Now in her fifties, tall and lean, she wears a discolored white sari draped across her bare torso and leaves her head uncovered like many elderly women in these villages. What makes her unlike the others is her outspoken manner and air of assertive self-sufficiency. She has been running her home-based paddymilling enterprise (manually processing paddy into parboiled rice) for nearly two decades.

Like all women from these rural parts, Sophura married at a young age. But the marriage lasted a very short time. Soon after her marriage, she gave birth to her first child, a daughter. Unhappy by this outcome, her husband left her in her father's house where she had gone to give birth and remarried again. The baby was only two months old at the time. Sophura could have recovered and returned to her marital home with her husband and claimed her place as the first wife. But she decided to remain in her father's house that was also home to her married brothers. Sophura continued living with her aged father and her brothers' families.

Self-conscious of her dependence on her married brothers, Sophura, started a small paddy-milling business to support herself and her daughter. She bought harvested paddy in bulk, frequently traveling to wholesale grain markets in the surrounding villages. Then she hired transportation to deliver the sacks of grain to her house. All of these transactions entailed haggling and required the ability to make speedy calculations. Once home, Sophura manually husked the paddy, separating the rice from the chaff, and then parboiled and dried the grain at home. The final step was selling this stock to the local rice mill where the grains were further milled and polished before being sold to retail establishments. Sophura recounts: 
You can't do this business without money. So, I had to take money from the moneylenders at an interest of ten percent (monthly). If I take Rs 5,000 (about \$114), 1 then I have to pay Rs 500 at the end of the month as interest. If I didn't borrow, then I wouldn't be able to run my business. And Rs 5,000 was nothing (compared to what was needed).

Sophura continued in this way for some years until her sister, who had been married into a wealthy family, decided that Sophura should get her share of their father's land. Having land in her name would prevent the possibility of her being "beaten and kicked out" empty-handed by her brothers after their father's demise. Their father owned 12 katha ${ }^{2}$ (.37 acres) of cultivable land that would pass on to his four children. Sophura's sister insisted that he divide the land equally between them while still alive. She relinquished her share to Sophura, entitling Sophura to six kathas of land.

Their father, afraid that his sons might disapprove, asked Sophura for payment in exchange for the land, forcing her to buy what should have been hers by inheritance. He decided to sell it to her a little below the market value, but her brothers insisted on the full market value. Sophura was forced to borrow Rs 6,000 from her business contacts to buy the land. Her next step was to build a house and set up an independent residence. The land she had acquired had a pond, so she borrowed an additional Rs 13,000 and had the pond filled in and built a thatched clay hut on it. To acquire these assets and keep her business running, she regularly borrowed from the local moneylenders at high interest.

Pointing to herself, Sophura emphatically proclaims, "Everything that I've done is with this body of mine." Subsequently, she had two more children from the estranged husband who offered no financial contribution toward their upbringing. She bore all the expenses singlehandedly, including the cost of her daughters' marriages. Through the years, Sophura had become a familiar face to the local moneylenders.

In 1997, almost a decade after she had started her business, Sophura heard about a local non-governmental organization (NGO) that was forming groups through which women like her would have access to low-interest loans. With her external high-interest debts piled high, Sophura enthusiastically volunteered to form and lead a group. She worked hard at gathering other women. The initial months were difficult. Men taunted them whenever they walked to their group meeting. Sophura remained firm, not paying any heed.

Once the loan cycle started, Sophura entered into a series of transactions. She took low-interest loans from the group and repaid her

\footnotetext{
${ }^{1}$ The 2004 exchange rate was about 44 INR $=1$ USD

${ }^{2} 1$ acre $=32$ katha
} 
high-interest debts with the moneylenders. She then used her income from the business to gradually repay the group loans. In her seven years of group membership, she has taken seven loans totaling Rs 20,000. With these loans, she has repaid all her external debts. Explaining her financial strategy, she says, "I've got to scale up the tree step-by-step. If I try to jump and get on top of it at one shot, then I'll fall and break my leg!" With her latest loan, she has bought a stretch of cultivable land adjacent to her house. She says with indignant pride, "I have debts from buying the land, not from eating!"

Sophura now has savings in the group, external institutional savings, and a life insurance policy. She speaks in vigorous appreciation of the financial relief microcredit has brought her:

What I like most is that now, even if there's a shortage or crisis, I don't have to spread my palms in front of others and beg for a bit of rice and worry about who'll give me a little bit of money....There've been times when I've paid more interest than capital. But in the group, the interest is low. So, we can take loans, repay the interest and capital, take another loan, and plan for investing it in business. I can buy 10, 15 sacks of paddy with these loans. When I need money, I take it from the group and work with it. I don't have problems any more.

She sums up the influence of the group, repeating the benefits of the loan:

I didn't have a 'guardian'; I was my own boss. So, I had to take the initiative and introduce myself to others. I had to do everything from buying to selling on my own...To buy paddy, I would go to the weekly markets in Keosha, Chandipur, and Sarapur which are all very far. Everyone loves me; I can get help from whomever I ask. Taking money from the moneylender was the biggest blight. We would be paying interest forever and the capital would still remain unpaid. But the situation improved gradually after joining the group. Now we're operating in a healthy way. At least I don't have to beg my neighbors for help: 'Lend me Rs 2,000 now, and I'll give you an extra Rs 200 when I repay you.'

Sophura and women like her, who had been managing on their own for decades, had an intense awareness of the cost of high interest borrowing. They were emphatic about the relief microcredit brought by allowing them to expand their small businesses and reduce their financial stress over borrowing from moneylenders.

\section{Entrepreneurship in De-facto Female-headed Households}

In some households the husbands were functionally absent from daily household management. These men had either migrated for work or 
were, in the words of their wives, slow-witted, indicating a certain mental deficiency or disinterest. Migrant husbands sent home remittances, but the wife was charged with running the household and making most of the decisions, sometimes in consultation with the long-distance husband. This experience of functionally managing on their own gave these women a certain degree of capability and confidence to try out income-earning initiative using microcredit loans. With their husbands away, these women were also somewhat free from the usual load of domestic responsibilities. The women married to slow-witted husbands learned to hold the reigns of their family early on soon after their marriage. These husbands were usually supportive of their wives' economic endeavors. They did not obstruct their wives from taking loans to try their hand at augmenting the family income.

\section{Case 2}

Tulsi Ray is 35 years old with no formal education. Her husband is a construction worker and has migrated to the western state of Gujarat to work on contract. His earnings range between Rs 2,000 - 3,000 per month; he remits back what he has left over after meeting his own living expenses. Tulsi has been managing the household ever since her marriage. Her husband has always been a migrant worker.

When the microcredit group started in her neighborhood, she played an instrumental role, along with a few other early enthusiasts, in convincing other women to join. When the loan cycles started, Tulsi took a loan of Rs. 7,500 and bought a jersey cow. A considerably more expensive breed than the local breeds, jersey cows have a higher yield of milk. A jersey cow gives $12 \mathrm{~kg}$. of milk per day. Tulsi says, "I know that even if I have to work all day after it, at the end of the day, it will give me at least 30 or 40 rupees (per day). I have been able to stand on my feet by selling the milk."

Tulsi's next loan of Rs 8,000 was used to buy another cow that she hoped would consolidate her financial success. But it failed to deliver the same results due to an unpredictable turn of events:

It was my idea (to buy the cow); I told him (her husband) about it. I have been able to repay the loan by selling milk even before it was due. I thought of buying another cow, and both of us would work on the cows. If he is there, it is convenient because tending to a cow is a lot of work since I am on my own. This time I took a loan of Rs 8,000 and bought another cow. The cow delivered a calf and, right after, it was infected with tetanus. Now, the cow has just a few bones left, and I have to spend a lot for its treatment. Just the other day, I paid the doctor Rs 500 to treat the cow. Now the situation is such that I don't have any money, and whatever I had made through the past year I have to spend on the cow. But we 
still cannot say if it will live or die. So, with this right now our situation has fallen a bit. If the condition of the cow was not like this, then I could have bought another one. But now it is such a disaster that I have to think of how to make ends meet. I still have to repay the loan...If this hadn't happened, then my situation would be very good and it's all because I joined the group. He (husband) had returned home prepared to give up his construction job (and participate with her in livestock rearing), but now he has had to leave again.

The crisis made the fate of her animal husbandry venture uncertain.

Case 3

There were women who had to take on the mantle of entrepreneurship because of their husbands' ineptitude. Kanan Biswas is 37 years old and has no education. She has a husband, a school-age son, and an 18-year-old daughter, who was married away at the age of 15 but brought back home to save her from an abusive husband. The family is landless. So, in order to start farming, they have taken possession of pawned off land. ${ }^{3}$ They now grow paddy on that land. Her husband works as a farm worker and earns daily wages of Rs 35 for the days that he finds work. Talking about her husband, Kanan says that he is slow-witted, that he is less clever than the average person. For that reason, she has had to manage everything. He is good-natured and a hard worker but lacks practical sense. Kanan manages the finances and makes all the decisions about farming and running the household.

In her four years in the group, Kanan has taken Rs 19,000 in loans for farming:

I do the work of cultivating the land we take. My husband understands less, so I have to budget and manage the cultivation and do the entire farming. I ask others how much fertilizer and pesticide we need for a piece of land and I go to the shop and buy the things as per their suggestions. And then my husband puts it in the field. All the shopkeepers sell me the pesticides and fertilizers. My husband doesn't quite understand these things, and everyone knows that it is not a problem to sell me these ${ }^{4}$.... First, I

\footnotetext{
${ }^{3}$ In a practice called "bondok", poor and financially struggling families pawn off their agricultural plots to moneylenders in exchange for money they may need for important expenses. Usually, land is pawned off only when families fall on dire circumstances and have no other means of generating income. The use rights over these pawned off lands are then passed on to other families, who cultivate the lands and pay the moneylender either in cash or through a share of the crop. ${ }^{4}$ Rural agricultural supply stores habitually refuse to sell fertilizers and pesticides to women. Consuming these substances is a very common method of
} 
took Rs 8,000 to take possession of a piece of land (pawned away). Then I took Rs 10,000 for cultivating it. I have twice taken Rs 500 from the group's savings fund for cultivation.

Kanan also has four native-breed cows and a goat. But the earnings from the livestock are not high. Native breeds produce less milk and the hay for their fodder is expensive. The money they make from selling milk, after deducting expenses, is sufficient for covering a few additional expenses. One benefit is that having these cows provides the security of being able to pay back loans by selling them, if the need arises - should their earnings fall below the repayment requirement. So far, this action has not been necessary. Instead she has been able to take up more land than before and expand her farming. Before she joined the group, the family refrained from borrowing from the moneylender, fearing the high interest rate. But with the relatively lower interest microcredit loans, she says she has gained the courage to borrow and expand the scale of her farming on credit.

Before, the way we always had shortages and complaints, we don't have that any more. Before we didn't have the courage to take money from anywhere and do something with it, but now we have the courage. I have saved some money. I have the courage in my mind that after some days I will get the money and do a particular work. We get courage in our hearts now.

\section{Entrepreneurship in Egalitarian Households}

There were only a few egalitarian households in the sample. The case described below is remarkable. It stands out because the business reached a sizeable scale within a few years and employed a significant number of women as it expanded. This example was the only one where a business had become large and profitable enough to generate employment beyond providing self-employment for the family.

\section{Case 4}

Kalyani Bayen's life has given her a remarkable story to tell. On the verge of becoming a college graduate, she withdrew before taking the final examinations. From a poor family, her father had contracted tuberculosis and could not cultivate the family land. The land had to be given up for sharecropping and the cows had to be sold off. Kalyani, the eldest child, had to take on the responsibility of earning a livelihood for the family. So, she enrolled in a livelihoods training program offered by the NGO that now operates the microcredit program. There she learned knitting

suicide for rural women. Therefore, a woman able to purchase fertilizers and pesticides directly was evidence of public acknowledgment of her leading role in farming. 
woolen garments using a knitting machine. For the next three years she remained affiliated with the NGO program and produced machine-knitted woolen garments. Gradually she saved up enough to buy her own machine.

After a few years, Kalyani married and moved to her husband's house with her knitting machine. Although her in-laws were quite well off with a sizeable family farm and savings, she started knitting and selling the woolen garments to a wholesale merchant. Her husband, a college graduate, managed the family farm. After a few years of seeing Kalyani at work, he learned how to operate the knitting machine from her. Then both started knitting woolens and selling them in bulk to the same trader.

When microcredit loans started to be given out, Kalyani took a loan of Rs 7,000. With a part of it, she bought more supplies and knitting machines, hired 10 women whom she taught to operate the machines, and set them to work for her. The rest of the money they spent on farming. Kalyani and her husband continued to work for the wholesale merchant but set up their own business on the side. Subsequently, they took loans of Rs 8,000 and Rs 10,000 and expanded their business. She trained and recruited more workers. At the time of data collection, Kalyani had 50 women working for her. She and her husband had stopped knitting, and the entire business was run on hired labor. Having taken out loans worth Rs 25,000, Kalyani had transformed from being a hired piecerate worker to an entrepreneur. She explains:

This is a seasonal business and, for instance, in the last season we gained Rs 30,000. This time we have two to three lakhs (roughly, $\$ 5000-7000$ ) worth of products, so this time the gains are likely to be more. But this time the price of wool has gone up and the number of people selling knitted garments has gone up, so the prices of the products have fallen. The selling season lasts for three months; the rest of the year we make the garments.

Both of us keep track of the loan money. When we get the raw material, I have to show the employees what kind of things we want made. As for the accounts, my husband keeps track of most of it, but I do know the basics of what we earn and spend. When he is not there, I have to take care of things. If someone else (wholesale merchants or retailers) comes to buy the things in bulk, then I have to negotiate with them and make the final sales. Then every Friday both of us go to the market to recover the money the retailers owe us.

Entrepreneurial transformation such as this is celebrated on the websites of microfinance organizations, but they happen so rarely that it makes them exceptional. 


\section{Entrepreneurship in Male-Headed Households}

An insignificantly small number of married women in conventional maleheaded households experienced loans as an incentive powerful enough to take the leap into entrepreneurship. In these cases, dire poverty threatened household subsistence and pushed women into entrepreneurship.

\section{Case 5}

After spending years as a conventional housewife who did not step outside the house and had no working experience, Bhanu Mondol tells of how she took the leap to taking loans. Forty-five-year-old Bhanu Mondol looked frail and had an air of being in a rush. Her demeanor was not surprising once she explained that, not long before, she used to work three shifts a day as a farmworker in the fields of local landowning families. Her family's financial situation has improved dramatically since then after she joined the microcredit group in her neighborhood. These improvements can be solely credited to her.

Five years ago, her family was landless and had no money to even take on land for sharecropping. The only source of income for the family of seven was her husband's meager daily income of Rs 30 from agricultural wage-work that fluctuated seasonally. Bhanu recalls those days of abject poverty, with the family facing severe food shortages and enduring other basic deprivations. Despite near-starvation conditions, she had never thought to find work as a farmworker: "Before I never used to go [outside the house to work in the fields] because I didn't have the habit."

Forced by poverty she decided to join the microcredit group. Once she joined, she took a very small loan of Rs 600 to pay off the sum they had borrowed at high interest from the moneylender to meet the family's subsistence needs. Grinding poverty and living in debt to the moneylender had not made her step out of the house in search of paid work. Surprisingly, the urge to repay the group loan and the incentive of taking another loan in the future pushed her against the force of habit into working in the fields. The daily pay for agricultural wage labor was only Rs 20. By the time the loan was repaid, two years had passed. Then she took a loan of Rs 1,500 and took on some land for cultivating paddy. Later, she stored the rice at home and repaid the loans by continuing to work in the fields.

Then, taking a huge leap, she borrowed Rs 10,000, a substantial sum considering the family's still fragile economic condition. She used part of that money to buy a "cycle-van," an open wooden pedal-driven mode of transportation in these villages. Her plan was to have her teenaged son operate the van as a transportation vehicle and bring in 
earnings through passenger fares. The rest she used for farming. Then, to repay the group's loan, she intensified her efforts to earn more. She started working morning, noon and evening, so that she could repay the sizeable loan and maintain her credibility in the group.

Throughout the entire day I would work in the fields, sometimes for three shifts: morning, noon, and evening. I'd work, and I'd constantly pray to god. When I gave my son the cycle-van I told him, 'Work hard and see that we can repay the loan in time. If we can keep our [financial] behavior all right then, in the future, we can take loans and start farming.

It took her an entire year to repay the loan through her own and her son's combined earnings. In this way Bhanu went from being a housebound wife-mother, struggling to make ends meet with her husband's abysmal income, to becoming a frenzied worker.

Once she realized that repaying loans on time meant the possibility of accessing future loans and moving to economic security, she shed her inhibitions. Eventually she cultivated land on her own behalf. To supplement her farmworker income, she started doing various other kinds of work. She bought vegetables and flowers in bulk at wholesale rates from the local farmers and then transported the produce to surrounding local markets, selling them at somewhat higher retail rates. She also hired herself out as a cook at village ceremonies.

Over the three years since she started farming, the amount of land she has rented for cultivation has steadily grown. Now the earnings from agriculture constitute a substantial part of the household's income.

Now we have two bighas 5 of land under cultivation, and I've purchased a plough. I also bought an ox with the money we made from selling crops. My husband uses the plough and the ox to plough other people's fields. I still work in the fields...I do everything; my husband is nothing! I take the loans, and I repay them. Even when it comes to farming, I do everything, from planting the seeds to buying and applying fertilizers and pesticides, harvesting the crop and selling them. I do everything!

With the newly acquired plough, her husband's earnings reach about Rs 800 per month during the paddy-sowing season, which lasts for six months a year. For the other six months, he sits at home idle. Bhanu declares vigorously that she works all 12 months and earns approximately Rs 700 every month. Her year-round income exceeds her husband's. On the home front, Bhanu is in charge of making all the decisions, from the allocation of funds for different household needs to the acquisition of agricultural supplies needed for farming and the repayment of debts. Their economic improvement is visible in the assets

\footnotetext{
${ }^{5}$ Roughly $1 / 3^{\text {rd }}$ acre.
} 
they have acquired and in her increased creditworthiness:

Now I'm happy. Before, none of these women [pointing to the other group members] would be ready to give me even 500 grams of rice, leave alone money. But now they'll give me Rs 5,000 if I ask for it. Now they'll give because I farm and I have an ox, a plough, and a van. So now everyone is willing to give, but before no one used to give me anything. They were scared that I wouldn't be able to return what I borrowed.

\section{Discussion}

Whether loans will spur women's entrepreneurship depends on a complex constellation of factors. Many of them would be considered misfortunes in rural Indian communities and, indeed, in many societies.

Women in female-headed households had to embrace entrepreneurship as a result of family adversity. They were forced into this path either due to marriage failure (i.e., widowhood or dissolution), which led them to be left on their own, often with children to take care of, or due to husbands who did not live up to the male breadwinner ideal. Women whose husbands had migrated away also entered into entrepreneurship. The remittances the husband sent back home were often inadequate or uncertain. And these women felt they could bolster their household income through a business of their own. Women in conventional male-headed households went on the path of entrepreneurship only when household survival became precarious, requiring their involvement in income-earning endeavors. For these women there were key enabling circumstances. First, these women resided in nuclear households, which meant there were no parents-in law or brothers-in-law to put normative restrictions on them and to prohibit or monitor their movements. Second, their husbands had extremely paltry earnings that were insufficient for meeting the family's basic necessities. Third, these men were not averse to their wives' behaviour of deviating from their traditional gender role. It is not possible to tell whether this attitude had been shaped by the hardship of poverty and the need to accept women's role in income generation or something else. Finally, none of these women had adult sons. If they had sons, they were still too young to take on an economic role. If adult sons were present then, instead of women starting businesses, it was typical to pass on the loans to a son to finance the son's business. Therefore, having an adult son made it less pressing for women to take on the work and responsibility of running a business in addition to their usual domestic responsibilities.

Taking a comprehensive look, it appears that entrepreneurship was not a matter of choice for most of the women; it was a last resort for survival. The only women for whom it involved some choice were those in 
relatively egalitarian households not under financial distress. Far from being the preferred path, "impoverished patriarchy" (Sanyal 2014) played a major role in the lives of these women who had to take the leap on to entrepreneurship. Surely, they exhibited entrepreneurial spirit and microcredit helped greatly to realize these goals. But abject poverty and their husbands' absence or failure to provide for the family, which is a breach of the traditional marital contract between the genders, cannot be overlooked. Table 1 encapsulates the common accompanying conditions, some linked to economic distress and some linked to loosening normative restrictions on women.

Table 1. Conditions Associated with Women's Entrepreneurship

\begin{tabular}{|c|}
\hline Marital failure \& need for self-reliance \\
\hline Husband's functional absence from household management \\
\hline Husband's paltry earnings \& abject poverty \\
\hline No adult son to contribute economically or to run a business \\
\hline Nuclear household residence \\
\hline Husband's accommodating gender attitude \\
\hline
\end{tabular}

An important finding from the larger study was that the pattern of loan use, rather than loan size, was the more significant predictor of the effectiveness of loans in increasing women's agency. Where microcredit facilitated women in hardship to take up farming or small businesses, it led to a transformative improvement in women's agency. There were economic improvements too, but without a longer-term study, it is difficult to comment on whether the gains were sustained over several years. Success of farming is susceptible to the vagaries of weather, and it is easy for health crises and household emergencies to draw away funds. Also, the scale of these enterprises is small, employing just the woman or her husband at best. Families do not necessarily seek to expand the size of their businesses knowing the limitation on the number of family members available to work.

The type of businesswomen usually start appears to depend a lot on the type of home-based industry in which women have expertise. In some types of work, women are able to circumvent the middleman and start their own businesses with loans. Tailoring is an example. But in other types of industries, like bidi (cheap cigarettes) making, which is the 
largest employer of women in these villages, women work on a piece-rate basis, and it is impossible for them to circumvent the middlemen. These subcontracting middlemen are agents of local companies that supply specialized raw materials and provide vital links to outside markets. They travel frequently to markets in towns and cities, maintaining the link between manufacturing bases and retail centers. For women in bidi making, there is no scope for taking advantage of loans to scale up or to become middlemen. These women remain trapped by the security of a predictable income even though it is extremely small. Such women and women without much experience outside of daily housework need more than just loans to enable them to start their own enterprises. They also need skills training to produce marketable goods.

Most previous studies on microcredit have brushed aside women's entrepreneurship, given its low incidence. Or, studies have not cared to distinguish between household businesses, overlooking who runs it, and businesses run primarily by women (Banerjee 2015 b). A few studies have been wholly critical of the claim of women's entrepreneurship in microfinance. For instance, a microfinance program and its linked poultry program sponsored by a well-known NGO in Bangladesh has been criticized for forcing the poorest women into becoming "chicken 'entrepreneurs'” (Karim 2011: 123-129). This article compensates for this shortcoming and rises above the critiques to undertake a comprehensive qualitative analysis of women's entrepreneurship. It contributes to a deeper understanding of the patterns and conditions related to women's entrepreneurship.

\section{Conclusion}

The emphasis on women's entrepreneurship has been criticized as neoliberal feminism celebrating woman microentrepreneurs as the heroines of structural adjustment and for constructing home-based women workers as nurturant entrepreneurs (Prugl 1999). While there is some value in these criticisms, it is difficult to imagine an alternative that is free from its own share of problems and criticism: state welfare provisioning, guaranteed minimum employment and wages of the kind already offered in rural India, government funded minimum income guarantee schemes, working as house maids, and salaried assembly line workers in factories.

From a practical standpoint, short of paradigmatic shifts in the economy and education levels that fundamentally improve labor market opportunities, it is not useful to cast aside microfinance and reject women's entrepreneurship wholesale. So, I conclude by suggesting some measures that might assist women who need or desire an independent livelihood to support themselves and their families. It would benefit women small-enterprise owners to offer linkages for their products to 
markets outside of their villages. Market hubs in major locations in the district and in urban centers for the direct sale of their products might expand their markets. Helping women producers form cooperatives or take up joint production when there is a good match of interest and skills might also be helpful. Linkages between these groups and major multinational retailers that have recently entered emerging market might enable product innovations, further retail support, and skill building. However, for all of these measures, the government or private agencies supporting microcredit programs must take the lead in negotiating these arrangements.

If women's entrepreneurship, rather than more holistic empowerment, is the main goal, then programs other than microcredit may also be considered. Cash transfer programs targeted at promoting new petty-trade enterprises can be considered. In Kenya, cash transfer programs with business skills training and mentoring and the requirement of forming a three-person group for running an enterprise jointly improved women's income, asset accumulation, savings, and livestock ownership (Gobin et al. 2017). Most of the enterprises involved women producing food-items. Interestingly, the matching time-use data showed there was a corresponding decline in women's leisure time and household activity. Another alternative is poverty "graduation" programs, typically offered to the ultrapoor. These programs provide a slew of monetary and non-monetary support (e.g., cash grants, credit, livestock, business training, supervision) for a limited duration until the recipients pull themselves out of poverty. This kind of program in Uganda benefitted women's enterprises based on petty trading, with ownership and income doubling (Blattman et al. 2016).

Today we live in a neoliberal capitalist world with degrees of patriarchy as the social context. While recognizing the constraints these systems put on us, it would be imprudent to shun women's entrepreneurship because of its popularization under this economic regime. There is value in women having the ability to embrace entrepreneurship when they are driven to it by necessity or out of their own desire. Women seem to recognize and value entrepreneurial possibilities even as they are skeptical and criticize microcredit practices and their "complicity with local patriarchies that exploit their labor and entrepreneurial activities" (Sen and Majumdar 2015). Also, owning and operating one's enterprise may start out as a simple economic activity for survival but, in time, may ignite social and political awakening. It may eventually lead to enhancing women's "capabilities" (Sen 1999), expanding their ability to participate in the social and civic life of a community and improve their quality of life. This cascading process of change has found support in recent evidence regarding group members' participation in grassroots political institutions in rural India (Palaniswamy et al. 2019, Sanyal 2019) and the development of self- 
efficacy beliefs among widowed and abandoned women enrolled in microcredit SHGs (Newransky et al. 2014).

An apt contemporary example to end with is the ima keithal, or the mother's market, in the northeast Indian state of Manipur (Barua and Devi 2004; Ram et al. 2016). This market is restricted to ever-married women sellers, with an overwhelming majority being middle-aged married women, followed by widows and divorcees. Nearly 5,000 of them operate in this market which is open to all buyers - women and men. This market has historical antecedents dating back 500 years, pre-dating British colonial rule. The local lore has it that an ancient system of forced labor prevailed here that took men from the Meitei community away to work as agricultural laborers and to fight wars in faraway lands. This prolonged absence of their husbands left the women in charge of their family's survival. The need to fend for the family is what may have led to the establishment of this market between 1500 and $1600 \mathrm{AD}$ to sell the produce grown by women. To this day it remains a bustling market that has weathered colonial suppression. These market women led agitations and uprisings against the British to force reform in trading rules and defend their market against being handed over to 'foreigners'. It continues to thrive into the twenty-first century as a major center of economic activity and informal social and political exchange among women in the state. This exemplar could serve as a model for advancing institutional support of women's entrepreneurship in India and globally.

\section{References}

Augsburg, B., De Haas, R., Harmgart, H. and Meghir, C. 2015. The Impacts of Microcredit: Evidence from Bosnia and Herzegovina, American Economic Journal: Applied Economics 7(1): 183-203. https://doi.org/10.1257/app.20130272

Angelucci, M., Karlan, D. and Zinman, J. 2015. Microcredit Impacts: Evidence from a Randomized Microcredit Program Placement Experiment by Compartamos Banco, American Economic Journal: Applied Economics 7(1): 151-82. https://doi.org/10.1257/app.20130537 Attanasio, O., Augsburg, B., De Haas, R., Fitzsimons, E. and Harmgart, H. 2015. The Impacts of Microfinance: Evidence from Joint-Liability Lending in Mongolia, American Economic Journal: Applied Economics 7(1): 90-122. https://doi.org/10.1257/app.20130489

Banerjee, A.V. 2013. Microcredit under the Microscope: What Have We Learned in the Past Two Decades, and What Do We Need to Know? Annual Review of Economics 5(1): 487-519. https://doi.org/10.1146/annureveconomics-082912-110220 
Banerjee, A., Duflo, E., Glennerster, R. and Kinnan, C. 2015. The Miracle of Microfinance? Evidence from a Randomized Evaluation, American Economic Journal: Applied Economics 7(1): 22-53. https://doi.org/10.1257/app.20130533

Banerjee, A. V., Karlan, D. and Zinman, J. 2015 b. Six Randomized Evaluations of Microcredit: Introduction and Further Steps, American Economic Journal: Applied Economics 7(1): 1-21. https://doi.org/10.1257/app.20140287

Barua, I. and Devi, A. 2004. Women Market of Manipur: An Anthropohistorical Perspective, Journal of Human Ecology 15(2): 129-133. https://doi.org/10.1080/09709274.2004.11905678

Becker, M.C., Knudsen, T., and Swedberg, R. 2011. The Entrepreneur: Classic Texts by Joseph A. Schumpeter. Stanford, CA: Stanford University Press.

Blattman, C., Green, E. P., Jamison, J., Lehmann, M. C., \& Annan, J. 2016. The Returns to Microenterprise Support among the Ultrapoor: A Field Experiment in Postwar Uganda, American Economic Journal: Applied Economics 8(2): 35-64. https://doi.org/10.1257/app.20150023

Crépon, B., Devoto, F., Duflo, E. and Parienté, W. 2015. Estimating the Impact of Microcredit on Those Who Take It Up: Evidence from a Randomized Experiment in Morocco, American Economic Journal: Applied Economics 7(1): 123-50. https://doi.org/10.1257/app.20130535

Gobin, V. J., Santos, P., \& Toth, R. 2017. No Longer Trapped? Promoting Entrepreneurship through Cash Transfers to Ultra-poor Women in Northern Kenya, American Journal of Agricultural Economics 99(5): 13621383. https://doi.org/10.1093/ajae/aax037

Davidson, T., \& Sanyal, P. 2017. Associational Participation and Network Expansion: Microcredit Self-Help Groups and Poor Women's Social Ties in Rural India, Social Forces 95(4): 1695-1724. https://doi.org/10.1093/sf/sox021

Kar, S. 2018. Financializing Poverty: Labor and Risk in Indian Microfinance. Stanford, CA: Stanford University Press.

Karim, L. 2011. Microfinance and its Discontents: Women in Debt in Bangladesh. Minneapolis, MN: University of Minnesota Press. https://doi.org/10.5749/minnesota/9780816670949.001.0001

Miles, M. B. and Huberman, A. M. 1994. Qualitative Data Analysis: An Expanded Sourcebook. 2nd edition. Thousand Oaks, CA: Sage.

Newransky, C., Kayser, K., \& Lombe, M. 2014. The Development of Selfefficacy Beliefs of Widowed and Abandoned Women through Microcredit Self-help Groups: The Case of Rural South India, Journal of Social Service Research 40(2): 201-214. https://doi.org/10.1080/01488376.2013.865579 
Palaniswamy, N., Parthasarathy, R., \& Rao, V. 2019. Unheard Voices: The Challenge of Inducing Women's Civic Speech, World Development 115: 6477. https://doi.org/10.1016/i.worlddev.2018.10.007

Prügl, E. 1999. The Global Construction of Gender: Home-based Work in the Political Economy of the 20th Century. New York, NY: Columbia University Press.

Ram, D., Singh, M.K., Chaudhary, K.P. and Jayarani, L. 2016.

Entrepreneurship Behaviour of Women Entrepreneurs in Imphal of Manipur, Indian Research Journal of Extension Education 13(2): 31-35.

Reuf, M. 2010. The Entrepreneurial Group: Social Identities, Relations, and Collective Action. Princeton, NJ: Princeton University Press.

Roy, A. 2010. Poverty Capital: Microfinance and the Making of Development. New York, NY: Routledge. https://doi.org/10.4324/9780203854716

Sanyal, P. 2009. From Credit to Collective Action: The Role of Microfinance in Promoting Women's Social Capital and Normative Influence, American Sociological Review 74(4): 529-550. https://doi.org/10.1177/000312240907400402

Sanyal, P. 2014. Credit to Capabilities: A Sociological Study of Microcredit Groups in India. Cambridge, UK: Cambridge University Press. https://doi.org/10.1017/CB09781139939461

Sanyal, P. 2015. Group-based Microcredit \& Emergent Inequality in Social Capital: Why Socio-religious Composition Matters, Qualitative Sociology 38(2): 103-137. https://doi.org/10.1007/s11133-015-9301-8

Sanyal, P., Vijayendra R., and Umang P. 2019. How Women Talk in Indian Democracy, Qualitative Sociology 42(1): 49-70. https://doi.org/10.1007/s11133-019-9406-6

Sen, D., \& Majumder, S. 2015. Narratives of Risk and Poor Rural Women's (Dis)-engagements with Microcredit-based Development in Eastern India, Critique of Anthropology 35(2): 121-141. https://doi.org/10.1177/0308275X15569850

Sen, A.K. 1999. Development as Freedom. New York, NY: Knopf.

Tarozzi, A., Desai, J. and Johnson, K. 2015. The Impacts of Microcredit: Evidence from Ethiopia, American Economic Journal: Applied Economics 7(1): 54-89. https://doi.org/10.1257/app.20130475

Yunus, M. 2007. Banker to the Poor: Micro-lending and the Battle against World Poverty. New York, NY: Public Affairs. 
Paromita Sanyal, Ph.D., is associate professor of Sociology at Florida State University. She is a qualitative sociologist who specializes in the study of development, gender, political sociology, and economic sociology. She has been researching public participation in grassroots political institutions in Indian democracy and the impacts of microcredit programs and self-help groups on economically disadvantaged women in India. Her research has been published in her award-winning book Credit to Capabilities: A Sociological Study of Microcredit Groups in India (Cambridge University Press, 2014) and Oral Democracy (Cambridge University Press, 2018). She has also published articles in the American Sociological Review, Social Forces, Qualitative Sociology, and The Annals of the American Academy of Political and Social Sciences. 